\title{
Culture Research in The Recent Work of Itamar Even-Zohar ${ }^{1}$
}

\author{
Harry Aveling
}

\begin{abstract}
ABSTRAK Even-Zohar sangat dihormati di kalangan peneliti Kajian Terjemahan untuk sumbangan teoritisnya dalam wilayah kajian "Polysystem Theory". Makalah ini memberikan pengantar ke karya terbaru Even-Zohar dalam wilayah "penelitian budaya" (yang ia bedakan dari Kajian Budaya). Karya tersebut menempatkan pemikirannya dalam kerangka kerja yang diturunkan dari Formalisme Rusia dan, yang lebih baru, Semiotika Rusia. Fokus utama makalahnya dalam Penelitian Budaya (2004/2005) adalah pada budaya sebagai sistem sosio-semiotika, yang memungkinkan adanya refleksi dan aksi. Sebuah istilah penting dalam membahas sistem-sistem adalah "repertoar", yaitu aturan-aturan dan materi-materi yang mengatur pembuatan dan penggunaan objek-objek budaya tertentu. Tulisan EvenZohar berusaha menempatkan repertoar di dalam kerangka kerja yang lebih luas, dan memungkinkan penemuan serta pemindahan repertoar-repertoar tersebut di antara kelompok-kelompok sosial. Peran para pembuat-ide sangatlah penting dalam pemindahan ini. Tulisan ini menyimpulkan relevansi "penelitian budaya" terhadap Kajian Terjemahan. Ini menunjukan bahwa ide-ide Zohar hanya dapat digunakan secara terbatas, tetapi mampu menyediakan dasar untuk refleksi lebih jauh tentang peran penerjemah dan penerjemahan, khususnya di banyak negara-bangsa baru.

KATA KunCI Itamar Even-Zohar, culture research, Translation Studies, Polysystem Theory, Russian Semiotics.
\end{abstract}

Itamar Even-Zohar is recognised as a major contributor to the development of Translation Theory during the so-called "cultural turn" of that theoretical field during the 1970s. ${ }^{2}$ This paper seeks to follow the development of EvenZohar's more recent work in the area he himself calls "culture research".

\section{ITAMAR EVEN-ZOHAR}

Itamar Even-Zohar was born in Tel Aviv in 1939, and educated at the universities of Tel Aviv and Jerusalem. He is currently Professor of Culture

1 This paper was first presented to the "Translation and/as Culture" Conference, School of Languages, Cultures and Linguistics, Monash University, 11-12 November 2005.

See Jeremy Munday, Introducing Translation Studies: Theories and Applications (Routledge, London 2001), Chapter 8 on "Varieties of cultural studies". 
Research and Porter Chair of Semiotics and Literary Theory, Tel Aviv University, having previously been Bernstein Chair Professor of Translation Theory (1973-1982) and Artzt Chair Professor of History of Literature (19821990). His major collections of works so far are Papers in Historical Poetics (PHP 1978); Polysystems Studies (PS 1990); and Papers in Culture Research (PCR 2004/2005). ${ }^{3}$

Even-Zohar's “Short Biographical Description” prepared for the Unit for Culture Research, Tel Aviv University in 2003, states:

His current main field is culture research. His main work has been developing polysystem theory, designed to deal with dynamics and heterogeneity in culture. His field work has concentrated on interactions between various cultures, and viewed them from the perspective of the making of cultures, especially of large entities (such as "nations"). He has been engaged in recent years in working on the planning of culture and its relation to the making of such large entities. In earlier stages of his work he contributed to developing a polysystemic theory of translation, i.e., designed to account for translation as a complex and dynamic activity governed by system relations rather than by a-priori fixed parameters of comparative language capabilities. This has subsequently led to studies on literary interference, eventually analysed in terms of intercultural relations. ${ }^{4}$

The main aim of this paper is to outline Even-Zohar's thinking on "culture", as presented in the Papers in Culture Research (2004/2005). One clarification is necessary before we advance. As Even-Zohar has stated in an interview with Dora Sales Salvador:

"Culture Research" is not identical with "Cultural Studies" because large parts of the latter are interested only in "the arts" and because they are often biased towards "lower strata" as an expression of protest against "the establishment". In Culture Research we attempt to avoid falling into the pitfalls of either "popular is authentic and true" or "popular is the degeneration of high values". ${ }^{5}$

$3 \quad$ Even-Zohar continues to update this third set of papers. I originally accessed them on his current website, http://www.tau.ac.il/ez_vita/ez-publications, on 10/4/2005, and the papers were then dated 2004. They are now dated 2005. There are two formats: one as "individual papers", the other as "the full version of the book". The 2005 edition adds one paper, "Intellectual Labor and the Success of Society", and omits one, "Culture Repertoire and the Access to Resources", which is the second half of an earlier paper, "Culture Repertoire and the Wealth of Collective Entities" (which is, at any rate, also available there). While allowing for changes between the individual papers and the full version, wherever possible page references included in the text below will be given to the 2005 full text.

$4 \quad$ Http://www.tau.ac.il/ itamarez/ez_vita/ez-eng.html, accessed 23/09/2003. Site no longer available.

5 Dora Sales Salvador, "In Conversation with Itamar Even-Zohar about Literary and Culture Theory", CLCWeb Library of Research and Information, 4:3, September 2002. On line at http://clcwebjournal.lib.purdue.edu/clcweb02-3/sales(even-zohar)02. $\underline{\mathrm{html}}$ (accessed 23/09/2003). 


\section{"Culture"}

There have been at least three separate ways of thinking about "culture" in the English intellectual tradition.

The first is suggested by Matthew Arnold's definition in his Culture and Anarchy (1869) that culture is "the best which has been thought and said in the world" 6 . This concept has led to the distinction between 'high' and 'popular' cultures, and an appreciation and preference for the former because of its aesthetic, intellectual and moral superiority.

A second standard, and equally old, definition is that of the British anthropologist Edward B. Tylor. In his book, Primitive Culture, published in 1871, Tylor wrote: "culture is that complex whole which includes knowledge, belief, art, morals, custom, and any other capabilities and habits acquired by man as a member of society". ${ }^{7}$

The second definition emphasises that culture is learned; complex; interrelated; and shared by all of the members of a society. It is the definition preferred by the social sciences. We may see its ongoing influence in the 1960s anthropological textbook Other Cultures, by John Beattie, which includes these chapter headings: Kinship, Marriage and Affinity, Social Control: Political Organization, Social Control: Law and Social Relations, Economic and Property Relations, The Field of Ritual: Magic, The Field of Ritual: Religion, Social Change, Conclusion and Assessment. ${ }^{8}$

Beattie recognised the role of language in the formulation of culture. He suggested that: "a people's categories of thought and the forms of their language are inextricably bound together." ${ }^{9}$ Another way of understanding this is expressed by Juliane House: "language is so embedded in culture such that the meaning of any linguistic item can be properly understood only with reference to the cultural context enveloping it." ${ }^{\prime 10}$

A third and subsequent view, strongly grounded in the functions of language, has been the theory that social life is "a world of symbolic connections". ${ }^{11}$ Ann Swidler's paper, "Culture in Action: Symbols and Strategies" (1986), greatly admired by Even-Zohar, noted the current acceptance by anthropologists of the argument that culture is composed of "the publicly available symbolic forms through which people experience and express meaning". ${ }^{12}$

\footnotetext{
6 Matthew Arnold, Culture and Anarchy (Cambridge UP, London 1960), p. 6.

7 Cited by E.L. Schusky and T.P Culbert (1978), Introducing Culture (Prentice-Hall, Englewood Cliffs NJ), p. 5.

John Beattie, Other Cultures (Cohen \& West, London 1964).

Beattie 1964: 31.

10 Juliane House, "Universality versus culture specificity in translation", in: Alessandra Riccardi (ed.), Translation Studies: Perspectives on an Emerging Discipline (Cambridge University Press, Cambridge 2002), p. 92.

11 J. Pouwer, Translation at Sight: The Job of a Social Anthropologist, Inaugural Address, Victoria University of Wellington, 1 August 1968, p. 6 - citing Marcel Mauss.

12 Ann Swidler, "Culture in Action: Symbols and Strategies", American Sociological Review, 51:2 (April 1986), p. 273.
} 


\section{Russian Formalism, Prague Structur alism}

This interest in language and symbolisation comes closest to Even-Zohar's thinking about "culture". Nevertheless, we must recognise that his own thinking has been overwhelmingly shaped by a completely different tradition: the work of the Russian Formalists of the 1920s, their successors the Prague structuralists, and the more recent Russian interest in Semiotics. ${ }^{13}$ These movements provided the foundation for the teaching of the Department of Poetics and Comparative Literature at Tel Aviv University, where Even-Zohar studied and in which he continues to teach. ${ }^{14}$

Language was central to Formalist definitions of literature and their successors, the Prague Linguistic Circle, further formulated Formulist literary theories within a purely linguistic framework. ${ }^{15}$ This framework was derived from, or at least very similar to, the ideas of Ferdinand de Saussure. ${ }^{16}$ In his Course in General Linguistics, first published in 1916, de Saussure argued that "languages are systems, constituted by signs that are arbitrary and differential."17 The Prague Circle was founded in 1926 by Roman Jakobson, after he moved to Czechoslovakia; Jakobson had also been the first chairman of the Moscow Linguistic Circle. The Prague School's emphasis on structures, as an alternative way of defining deSaussure's concept of relationships, led to it being described as "structuralist". They argued that, like language, the poetic work too is a "'functional structure' ... the different elements of which cannot be understood except in their connections with the whole". ${ }^{18}$

The Prague school applied these ideas of "structure" and "function" not only to literature but in fact to all forms of communication. In an address delivered in America in 1958 but based on categories propounded by Mukarovsky twenty years earlier, Jakobson suggested that any message can have six different functions. These correspond to the six factors present in any act of communication: an addresser, an addressee, a context, a code, a means of contact, and the message itself:

\section{CONTEXT}

ADDRESSER

\section{MESSAGE}

CONTACT

\section{CODE}

13 Russian literature held the position of major prestige in "the Hebrew literary polysystem" between the two wars, and continued to do so long afterwards, as Even-Zohar explains in PS, p. 49 and p. 83.

$14 \quad$ See Rachel Weissbrod: "Translation Research in the Framework of the Tel Aviv School of Poetics and Semiotics" ,Meta, XLIII:I (1998), pp. 1-12, on line at: www. erudit.org/revue/meta/1998/v43/n1/004592ar.html

15 David Robey, "Modern Linguistics and the Language of Literature", in: Ann Jefferson and David Robey (eds), Modern Literary Theory (Batsford, London 1982), p. 36.

16 Robey 1982: 43.

17 Robey 1982: 39.

18 Robey 1982: 44. 
These functions work in the following way:

\begin{abstract}
The focus on the addresser, for instance a speaker or an author, constitutes the emotive function, that of expressing the addresser's attitudes or feelings; the focus on the addressee or receiver, the conative function, that of influencing the feelings or attitudes of the addressee; the focus on the context, the real, external situation in which the message occurs, the referential function; the focus on the code, as when the message elucidates a point of grammar, the metalingual function; the focus on the means of contact, as in the case, say, of expressions inserted by one party into a telephone conversation simply in order to reassure the other party that they are both still on the line, the phatic function; the focus on the message itself, the poetic function. ${ }^{19}$
\end{abstract}

While all functions may be present within any speech event, one will normally be dominant. ${ }^{20}$ This function will stand out beyond all the other functions in some obvious manner and will thus "foreground" or "actualise" the text as a whole. ${ }^{21}$ Sometimes the message may be the most important thing about a text. At other times, the personality of the artist dominates everything else. On still other occasions, the means of expression may be the main feature of interest and the major distinguishing characteristic of the text. Acts of communication are also, therefore, both "hierarchical" (some are more important than others) and "dynamic" (constantly changing).

\title{
Russian Semiotics and the Papers in Culture Research
}

Equally relevant for Even-Zohar's work on culture are more recent semiotic developments in Russian thought. Ann Shukman has written that, following the death of Stalin and the vacuum created in Soviet intellectual life by a lack of strict ideological control, Semiotics emerged in Russia as:

virtually the only voice to concern itself to concern itself with problems of culture and the theory of the arts. It then came to claim all fields of culture as its domain and hence cultural universals as its central topic. ${ }^{22}$

A new phase of the semiotics movement took place at Tartu University, under Yu. M. Lotman, who developed a "concentration on 'secondary modelling systems,' by which he meant those cultural systems (literature, the arts) which are 'secondary' in relation to language, which is held to be the "primary' modelling system". Linguistics was "largely excluded from consideration" and the focus fell on "particular cultural systems (myth,

19 . Robey 1982: 44-45. The article has recently been reprinted as "Closing Statement: Linguistics and Poetics", in Jon Cook (ed.), Poetry in Theory (Blackwell, Oxford 2004), pp. 350358.

20 Peter Steiner defines "the dominant" as "a skeletal, form-giving element in a static hierarchy of holistic correlations", Russian Formalism, Cornell University Press, Ithaca NY 1984, p. 105. See Jakobson's essay “The Dominant" in L. Matejka and K. Pomorska (eds), Readings in Russian Poetics (MIT Press, Cambridge 1971), pp. 82-87.

21 Robey 1982: 45.

22 Ann Shukman, "Soviet Semiotics and Literary Criticism", New Literary History, 9:2 (Winter 1978), p. 190. 
ritual, religion, as well as folklore and the arts) rather than with cultural universals." 23

After 1970, Lotman moved towards a semiotic theory of culture. This too was not entirely a move away from his previous interest in literature. As Shukman states in her study of Lotman: "In these studies of culture, literature, if not the point of departure, was always at least the illustrative material." ${ }^{24}$ Later in her book Shukman more emphatically points out that in Lotman's essays from the late 1960s: "He describes culture as the sum-total of all literary activity at a given epoch; it is not just a collection of 'great names' and isolated masterpieces" 25 (underlining added).

The concept of "culture" plays a limited role in Even-Zohar's early work. Its presence is most striking in the article "On Systematic Universals in Cultural History" (1977), collected in the Papers in Historical Poetics. Even-Zohar opens his discussion with a summary statement which may serve as a guiding thread to all that is to follow in his paper:

The overall conceptual framework which semiotics tried to provide for the sciences of man [...] was always dominated by the idea of human activity as an aggregate of sign systems carrying information, i.e., a system of systems necessarily correlated and functioning despite their heterogeneity as a structured whole. ${ }^{26}$

Even-Zohar then continues with a quotation from a recent article by Yury Lotman and some of his colleagues, Uspenskij, Ivanov, Toporov and Pjatigorskij:

In the study of culture, the initial premise is that all human activity concerned with the processing, exchange, and storage of information possesses a certain unity. Individual sign systems, though they presuppose immanently organised structures, function only in unity, supported by one another. None of the sign systems possess a mechanism which would enable it to function culturally in isolation. Hence it follows that, together with an approach that permits us to construct a series of relatively autonomous sciences of the semiotic cycle, we shall admit another approach, according to which all of them examine particular aspects of the semiotics of culture, of the functional correlation of different sign systems. ${ }^{27}$

He then follows this up immediately with a further series of quotations from the same source, stating:

Consequently, the authors believe, 'culture is constructed as a hierarchy of semiotic systems' and "it is 'precisely [this] inner structure, the composition and correlation of particular

23 Shukman 1978: 190-191.

24 Ann Shukman, Literature and Semiotics: A Study of the Writings of Yu. M. Lotman (North-

Holland, Amsterdam 1977), p. 87.

25 Ann Shukman 1977: 102.

26 Even-Zohar, "On Systematic Universals in Cultural History", PHP, p. 38.

27 J.M Lotman, B.A.Uspensky, V.V. Ivanov, V.N. Toporov, and A.M. Pjatigorskij (1975), "Theses on the Semiotic Study of Cultures (as Applied to Slavic Texts)", in: T.A. Sebeok (ed.), The Tell Tale Sign: A Survey of Semiotics (The Peter de Ridder Press, Lisse 1975), p. 57. 
semiotic subsystems, which determine the type of culture in the first place' (ibid., 61). They admit that 'several cultures may also form a functional or structural unity' and that 'such an approach proves especially fruitful in solving problems of the comparative study of culture' (ibid.). Thus, 'culture' is considered the highest regulating principle of organised human activity, which, by means of its subsystems, manages to structure the world for human society. ${ }^{28}$

This leads him to a second article by Lotman and Uspensky, from "On the Semiotic Mechanism of Culture" (1978), and the statement:

The main work of 'culture' [...] is the structural organisation of the surrounding world. Culture is a generator of 'structuredness' and it creates social sphere around man which, like biosphere, makes life possible (in this case social and not organic). But in order to fulfil this role, culture must possess a structural 'stamping device'. This function is carried out by natural language. The language imparts an intuitive feeling of structure to all members of the community: by its evident systemic nature [...], by its transformation of an 'open' world of realia into a 'closed world of names, language makes people treat as structures even such phenomena the structural nature of which is, at least, not self-evident. ${ }^{29}$

Even-Zohar (1978) concludes the first part of his paper, "On Systematic Universals in Cultural History", with the claim that the semiotic idea of culture is "capable of becoming a powerful working hypothesis, tightly linked with 'both language and literature' in a concrete way" (underlining added), and that "we have little choice as whether or not to use it". Thus:

[...] even if our individual points of departure are language, literature, sociology, history, fashion or public traffic, we are likely to reach a point at which we cannot proceed satisfactorily unless we consider our specialised fields as both iso-structural and correlated with culture, that is both structuring it and structured by it..$^{30}$

In "The Making of Culture Repertoire and The Role of Transfer" (1997), $P C R$, Even-Zohar again uses these same quotations from Lotman. Here, however, he also makes reference to the article by the American anthropologist Ann Swidler cited above, to suggest that culture is "a repertoire or 'tool kit' of habits, skills and styles from which people construct 'strategies of action'" ${ }^{31}$ The use of Swidler's 1986 article may suggest a shift away from literary models, which were characteristic of the early work of Lotman and of Even-

28 Even-Zohar, "On Systematic Universals in Cultural History”, PHP, p. 39.

29 Even-Zohar cites these words as "quoted from Segal, 1974: 94-95"; the reference to the original Russian publication, but not to Segal, is given in the composite Bibliography to the PHP. (It does occur in "The Making of Culture Repertoire and the Role of Transfer", PCR - Dmitri Segal: Aspects of Structuralism in Soviet Philology, Porter Institute, Tel Aviv 1974.) A full translation of the article is available in New Literary History, 9:2 (Winter 1978), pp. 211-232; the quotation occurs at the top of page 213.

30 "On Systematic Universals in Cultural History", PHP, p. 40. In the paper on "The Polysystem Hypothesis Revisited" (1977), Even-Zohar repeats the assumption that "the literary PS is just a component of a larger PS - that of 'culture' to which it is, semiotically speaking, both subjugated and ismorphic [...] and thus correlated with this greater whole and its other components", PHC, pp. 28-29.

31 Swidler 1986: 273. 
Zohar himself. This need not necessarily be the case if we read Swidler with Even-Zohar's particular interests in mind. She has written:

[...] culture consists of such symbolic vehicles of meaning, including beliefs, ritual practices, art forms, and ceremonies, as well as informal cultural practices such as language, gossip, stories, and rituals of daily life. These are the means through which 'social processes of sharing modes of behaviour and outlook within [a] community' (Hannerz 1969: 184) take place. $^{32}$

The words can be read as describing a broad range of patterned oral and written textual practices. They certainly should not necessarily be read as referring to those aspects of culture around which Beattie has written his book: kinship, marriage, political organisation, law, economics, magic and ritual, or social change. Even-Zohar's use of Swidler allows him to continue to work in broader but still essentially literary-like fields.

\section{Papers in Culture Research}

The semiotician of culture, Even-Zohar suggests, is interested in "the interaction between the material and semiotic processes in culture" ${ }^{33}$ In the second of the Papers on Culture Research, "Factors and Dependencies in Culture: A Revised System for Polysystem Culture Research" (originally published in 2000 and halved in PCR), Even-Zohar defines culture as "an overall system, a heterogeneous set of parameters, with the help of which human beings organise their life". ${ }^{34}$ More precisely, culture is a socio-semiotic system, defined as "a sign-governed pattern of communication", one of a number of such systems, some others being language and literature..$^{35}$

As the title to the first paper suggests, there are two major concepts of "culture", "Culture as Goods, Culture as Tools". Even-Zohar firstly describes what we might consider to be Matthew Arnold's view in terms of "cultureas-goods". He suggests that this concept is characteristic of everyday use and of the humanistic traditions. The possession of these goods - whether they be objects, ideas, activities or artifacts, "lapis lazuli, a high palace, running water, a car, a computer, or a set of texts [...]" - signifies "wealth, high status, and prestige". The "value" of these goods constantly changes, and it is the privileged who have most access to such goods and define their value in the first place, using such terms as "original", "artistic", "aesthetic", "spiritual" and so forth. Those producers of cultural goods who have their products recognised as valuable gain the benefits and rewards known as "success". (Here Even-Zohar pays tribute to the work of the French sociologist, Pierre Bourdieu, whom he also acknowledges in the Introduction to PS as "in

\footnotetext{
$32 \quad$ Swidler 1986: 273. The included reference is to Ulf Hannerz, Soulside: Inquiries into Ghetto Culture and Community, (Columbia University Press, New York 1969).

33 "Language Conflict and National Identity", PCR, p. 140.

34 "Factors and Dependencies in Culture', as published in Canadian Review of Comparative Literature, 24:1 (March 1997), p. 17.

${ }_{35}$ "Polysystem Theory Revised", PCR, p. 42.
} 
some areas superior [...] to both Russian Formalism and later developments (including my own)", p. 3. $)^{36}$

The second concept, of "culture-as-tools", is characteristic of anthropology and sociology, but also of cultural semiotics. Here "culture is considered as a set of operating tools for the organization of life, on both the collective and individual levels". These tools are also of two types. "Passive tools" are "procedures with the help of which 'reality' is analyzed, explained and made sense of for and by humans". In this particular regard, he again cites Lotman's view that "the world" is "a set of signs which [...] bombard us daily, and therefore need to be interpreted in order to make life possible" ${ }^{37}$ Passive tools are about understanding. "Active tools", on the other hand, are about acting. They are "procedures with the help of which both an individual and a collective entity may handle any situation encountered, as well as produce any such situation". ${ }^{38}$

The distinction collapses in "Culture as Goods, Culture as Tools", when Even-Zohar insists that:

the 'culture-as-tools' conception is more useful and allows greater analytical and research versatility for developing research and understanding - and eventually also practical tools for policy-making - in the field of culture. Moreover, 'goods' can be fully investigated within the tools-framework, while the opposite is not true. ${ }^{39}$

The key term for understanding both "passive" and "active" tools is "repertoire", which suggests that tools "are not a random pile of options, but a complex set, an array of interrelated components".$^{40}$ The term "repertoire" is drawn from Even-Zohar's redefinition of Jakobson's six functions of language. In the second essay, "Factors and Dependencies in Culture: A Revised Outline for Polysystem Culture Research" (1997), Even-Zohar outlines these six as follows:

a. The repertoire (code) is "the aggregate of rules and materials which govern both the making and handling, or production and consumption, of any given product".

b. The product (message) is "any performed set of signs, i.e., including a given behaviour".

c. The producer (addresser) is "an individual who produces, by actively operating a repertoire, either repetitively producible or 'new' products".

\footnotetext{
36 This paragraph summarises "Culture as Goods, Culture as Tools", PCR, pp. 7-10.

37 See footnote 26 above, for references.

38 This paragraph summarises "Culture as Goods, Culture as Tools", PCR, pp. 10-12. In "The Making of Culture Repertoire and the Role of Transfer" (1997), Even-Zohar isolates Swidler's definition of culture as "a repertoire or 'tool kit' of habits, skills and styles from which people construct 'strategies of action'”, and frames it completely within the culture-as-tools approach.
}

39 "Culture as Goods, Culture as Tools", PCR, p. 10

40 "Culture as Goods, Culture as Tools", PCR, p. 12 
d. The consumer (addressee) is "an individual who handles an already made product by passively operating a repertoire".

e. The institution (context) consists of "the aggregate of factors involved with the control of culture. It "governs the norms, sanctioning some and rejecting others", "remunerates and reprimands producers and agents", and "determines which models (as well as products, when relevant) will be maintained by the community for a longer period of time".

f. The market (contact) is "the aggregate of factors involved with the selling and buying of the repertoire of culture, i.e., with the promotion of types of consumption". ${ }^{41}$

In the essay, "The Making of Culture Repertoire and the Role of Transfer" (1997), Even-Zohar repeats that: "the major concept in the theory of culture I employ" is that of repertoire, defined as "the aggregate of options utilised by a group of people, and by the individual members of that group, for the organisation of life" ${ }^{42}$ He considers the concept at some length, discussing "the structure of the repertoire" (comprising "individual elements and models"); "the dynamic parameters of repertoire usage"; "the making of repertoires"' "the making of repertoire and the institution" and "repertoires and identities".

But this essay also adds two important new concepts to Even-Zohar's discourse formation. The first is indicated in the term "group of people". Even-Zohar uses this term extremely loosely. It may refer to "a large group of people living on a certain territory, normally referred to as 'society', but also to a small number of people living in the same apartment, normally referred to as 'a family". In either case, they are "aggregates of people whose life is organised by a certain culture". ${ }^{43}$ This shift is the foundation for the third part of his book on the more practical aspects of "Culture Planning" (which I shall not pursue here).

The second conceptual development is the reference to the two major procedures for making new repertoires: "invention" and "import". ${ }^{44}$ The discussion of "import" leads to old discussions of "transfer", and its success in situations in which there is an "absence" in the targeted group; a "willingness to consume new goods"; "when new situations are introduced [...] and there no, or a slight, home repertoire to handle them"; or "if the other repertoire is richer, more prestigious among many groups, or may even promise 'a better life $^{\prime \prime \prime} .45$

\footnotetext{
41 "Factors and Dependencies in Culture Research", PCR, pp. 14-35.

42 "The Making of Culture Repertoire", PCR, p. 73.

"The Making of Culture Repertoire", PCR, p. 73

"The Making of Culture Repertoire", PCR, p. 77.

"The Making of Culture Repertoire", PCR, pp. 77-78. Compare with "The Position of Translated Literature within the Literary Polysystem", PS, pp. 47-49; "Laws of Literary Interference", PS, pp. 53-73, and its revised form, "Laws of Cultural Interference", PCR, pp.
} 54-71. 
"Invention" itself leads in new directions, to "people engaged in the making of repertoire who are, in the particular case of transfer, agents of transfer" ${ }^{46}$ This shift provides a foundation for the third part of the book, as well as for the fourth part, "Intellectuals and Success". In this regard, Even-Zohar's greatest interest still falls on texts, and particularly "on a small group of people [...] popularly known under various titles, such as 'writers', 'poets', 'thinkers', 'critics', 'philosophers' and the like, [who have] produced an enormous body of texts in order to justify, sanction and substantiate the existence, or the desirability and pertinence of [...] the German, Bulgarian, Italian and other nations". ${ }^{47}$ In some cases, they have also produced themselves: "For example, states of mind and encouragement to act for 'freedom', 'heroism', 'patriotism', 'equality', or less stirring acts like 'cleanliness', 'order', or 'good food', are not derived from 'writings', but from what one has heard of the 'writers' which often falls into the category of myth." 48 The more recent papers in these later parts of PCR deal with "idea-makers"; "cultural entrepreneurs"; "makers of life images"; while not forgetting the "thousands of agents [...] recruited to popularise the texts of the few initiators, and to spread the language they used in these texts", namely "teachers and [...] intellectuals". ${ }^{49}$

\section{Coming BACK to TRAnSLATION StUdies}

Even-Zohar's work on literary polysystem was extremely important for systematic thinking about the nature and work of translation between nations. Can this shift in his thought be of use to those of us who continue to work in Translation Studies?

A first answer might be: "not at all". Even-Zohar has made his contributions to Polysystem Studies and moved away from literary translation to broader concerns. This shift is further marked by an assumedly non-ideological perspective. As Nam Fung Chang pointed out in his presentation to the Historical Translation Research Seminar at the University of Manchester in 2000, Even-Zohar's recent re-writings of his papers have deleted nearly all references to ideology, power, politics, economics, language and literature, except in the most general terms. ${ }^{50}$ On the other hand, the "cultural turn" in Translation Studies is very much concerned with: "how values, ideologies, and institutions shape practices differently in different historical periods." ${ }^{1}$ Translation Studies and Culture Research are different academic areas, now working in different directions, and should be left to do so.

\footnotetext{
46 "The Making of Culture Repertoire", PCR, p. 79 (punctuation amended).

47 "The Role of Literature in the Making of the Nations of Europe: A Socio-Semiotic Examination", PCR, p. 129.

48 "The Making of Culture Repertoire", PCR, p. 79.

49 "The Role of Literature", PCR, p. 133

50 "The 'Cultural Turn' of Itamar Even-Zohar's Polysystem Studies - Promises and Problems", abstract, http:www.ccl.umist.ac.uk/events/conference/history1.htm. Subsequently published as Nam Fung Chang: "Polysystem Theory: Its prospect as a framework for translation research", Target, 13:2 (2001), pp. 317-332.

51 Lawrence Venuti, “American Tradition”, in: M. Baker (ed.), Routledge Encyclopedia of Translation Studies, (Routledge, London 1998), p. 315.
} 
A second, more startling, answer also suggests itself. In a footnote to "Laws of Cultural Interference", Even-Zohar (2004/2005) notes:

This is a rewriting of my paper "Laws of Literary Interference", Poetics Today 11:1, pp. 5372 (based in its turn on ["Universals of Literary Contacts", PHP, pp. 45-52]), adapted to the field of culture research. This conversion has been relatively unproblematic, because the proposals in the original paper actually transcended the restricted field of "literature" from the outset and were almost integrally applicable to the larger field of culture.

Translation theorists might be tempted to think, therefore, that a further amount of back-translation might suffice as a way of establishing what, if anything, is new and useful in the Papers in Culture Research for their purposes. To do this, leads us to recognise the importance of the newer developments, especially the concept of "repertoire". ${ }^{52}$ It encourages us to consider the discussions relating to the roles of language and literature, and therefore translation as well, in the formation of new nation-states. Finally, it asks us to explore the work of translators as agents of change, using frameworks other than those already established by feminism and postcolonial theory.

A third option in dealing with Culture Research leads us back to the recognition that language and culture (however we define the term) are intimately related, and that this relationship is crucial to the work of translation. If we do this, we will acknowledge the importance of what EvenZohar is attempting, even if we cannot accept his results, as many still can not. Anthony Pym, for example, has suggested that "much of translation history can advance quite well without using the word 'system' at all". ${ }^{53} \mathrm{He}$ finds the systems postulated by Even-Zohar are ultimately vague; they rely on "leaps of faith"; they "suppress a humanized, subjective systematicity"; and that, while system theories in general aim to be "scientific", they are "not very good [...] at formulating causal hypotheses" or, equally important, in putting forward ethical propositions. ${ }^{54}$ This would still seem to apply to the Papers in Culture Research.

Edwin Gentzler, too, while acknowledging "the advances" made by EvenZohar, also notes four "minor problems" with Polysystem theory which would seem to be equally applicable to Culture Research. These are: a "tendency to propose universals based on very little evidence"; an "uncritical adoption of the Formalist framework" and some of its concepts which "underlie, yet seem inappropriate to [...] [his] complex model of cultural systems"; "the problem of locating the referent"; and, finally, "Even-Zohar's own methodology and discourse", with its assumed scientific objectivity and assumptions of total

52 See the relevant articles by Anthony Pym: "Note on a Repertoire for Seeing Cultures", Target, 10:2 (1998), pp. 357-361; José Lambert, “Itamar Even-Zohar's Polysystem Studies: An Interdisciplinary Perspective on Culture Research", Canadian Review of Comparative Literature, 24:1 ( March 1997), pp. 8-14, and Even-Zohar's "Some Replies to Lambert and Pym", Target, 10:2 (1998), pp. 363-369.

53 Method in Translation History (St Jerome, Manchester 1998), p. 117.

54 Method in Translation History, pp. 116-124. 
completeness. ${ }^{55}$ These problems (which are obviously not "minor" at all) suggest the need for further conceptualisation of Even-Zohar's premises. They do not necessarily negate the premises, but certainly call for caution in their application, while encouraging us to do better ourselves.

\section{APPENDIX:

$$
* * *
$$ \\ A Basic Outline of Polysystem Theory ${ }^{56}$}

Even-Zohar writes that: "Polysystem theory was suggested in my works in 1969 and 1970, subsequently reformulated in a number of my later studies and (I hope) improved, then shared, advanced, enlarged, and experimented with by a number of scholars in various countries. ${ }^{\prime 57}$ Its foundations had been "solidly laid" by the Russian Formalism of the 1920s (as he notes on page 1 of his "Introduction to Polysystem Studies"), especially by its later transformation "from an a-historical, clearly textocentric, approach to one where above-thetext occurrences are considered to be the main factor, and change is considered a built-in feature of 'the system' rather than 'an external force'" (33).

The main ideas of Polysystem Theory can be reduced to a small set of propositions. These can be logically set out as follows, using Even-Zohar's own words as far as possible:

1. The term "literary" refers to "any kind of textually manifested (or manifestable) semiotic repertoire fully and visibly institutionalised in

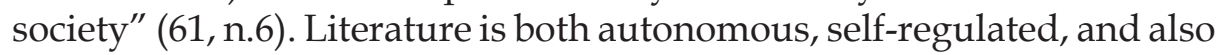
heteronomous, in as far as it is conditioned by other systems (30).

2. A "system" is "the network of relations that can be hypothesized for a certain set of assumed observables" (27). ${ }^{58}$

3. A "literary system" is "the assumed set of observables supposed to be governed by a network of relations (i.e., for which systemic relations can be hypothesized), and which in view of the hypothesized nature of these relations we propose to call 'literary'" (27). Alternatively it is: "The network of relations that is hypothesized to obtain between a number of activities called 'literary' and consequently these activities themselves observed via that network" (28). As a consequence, Even-Zohar suggests

55 Contemporary Translation Theories, pp. 120-123. See also Jeremy Munday, Introducing Translation Studies (Routledge, London 2001), p. 111.

56 This summary is drawn from my forthcoming article: "Two Approaches to the Positioning of Translations: A Comparative Study of Itamar Even-Zohar's Polysystem Studies and Gideon Toury's Descriptive Translation Studies and Beyond", to appear in Kritika Kultura, an e-journal published by the English Department of Ateneo de Manila University, Philippines.

57 "Introduction to Polysystem Studies", Poetics Today, 11:1 (1990), p. 1. Page references will subsequently be included within brackets in the main text, as accessed 23/09/2003.

58 In his essay "On Literary Evolution" (1927), Tynjanov defines "the system" as "a complex whole, characterized by interrelatedness and dynamic tension between individual components, and held together by the underlying unity of the aesthetic function": see V. Erlich, Russian Formalism, (Mouton, The Hague 1969), p. 199. 
that: “THE literary system does not 'exist' outside the relations contended to operate for/in it" (28).

4. Following Jakobson ${ }^{59}$, Even-Zohar argues that the factors involved within the literary (poly)system are:

a. The producer (addresser, the writer), who makes texts, as both a "conditioning" and a "conditioned" force (35).

b. The consumer (addressee, reader or listener), who "consumes" the text, but also engages in a wider range of activities relating to literature as part of "the public" (36-37).

c. The institution (context), which "governs the norms prevailing in this activity ... remunerates and reprimands producers and agents ... determines who, and which products will be remembered by a community for a longer period of time". The institution includes critics, publishing houses, periodicals, clubs, groups of writers, government bodies, educational institutions, the mass media, and more (37). Because of this diversity, it is clear that the literary institution is "not unified" (38).

d. The repertoire (code), which is "the aggregate of rules and materials which govern both the making and the use of any given product" (39). Repertoires are structured on at least three levels (40-41). In traditional linguistic terms, the repertoire is "a combination of 'grammar' and 'lexicon' of a given 'language" (39). The "literary repertoire" is "the aggregate of rules and items with which a specific text is produced, and understood". The literary repertoire may also include "the shared knowledge necessary for producing (and understanding) various other products of the literary system", such as the roles of 'writer', 'reader', 'literary agent', etc. (40).

e. The market (contact, channel), which is "the aggregate of factors involved with the selling and buying of literary products and with the promotion of types of consumption" (38). And, finally:

f. The product (message), which is "any performed (or performable) set of signs, i.e., including a given 'behaviour'” (43).

5. A "polysystem" is "a multiple system, a system of various systems which intersect with each other and partly overlap, using concurrently different options, yet functioning as one structured whole, whose members are interdependent" (11). Polysystems are "dynamic" and heterogeneous (12). They are "not equal, but hierarchized" (14): "It is the victory of one stratum over another which constitutes change on the diachronic axis" (14).

6. At the centre of each particular system is "the most prestigious canonized repertoire" (17). Change commonly comes from "the periphery" to the center, within systems and sometimes across systems (14).

7. Literary systems are always in contact with other literary systems -- Even-

59 David Robey 1982: 44-45. 
Zohar's ponderous words are: "Literatures are never in non-interference" (59). Sometimes this interference is direct: "a source literature is available to, and accessed by, agents of the target literature without intermediaries". At other times it is indirect: "interference is intermediated through some channel such as translation" (57).

Translated literature plays a particular role within the literary polysystem, but always on terms set by the receiving literature - not those of the source literature itself (46) - and prestige and dominance are important elements in this process (59). The home co-systems of the target literature also determine "the way they adopt specific norms, behaviours and policies - in short, their use of the literary repertoire" (46). It is important to note two implications of this. The first is that "an appropriated repertoire does not necessarily maintain source literature functions" (59); instead it meets the functions determined by the needs of the receiving literary system. It is also the case that any translation will create a different text from the source text: one that is "simplified, regularized, [and] schematized" (59).

Translated texts may have various positions in the literary polysystem. They may sometimes even become central and "the most active system within it" (46). This happens when a polysystem is still being established; when the literature is peripheral within a group of co-related literatures, or weak, or both; and when there are "turning points, crises or literary vacuums within the literature (47-48). Translated texts may also be "peripheral", in which case their function is largely conservative (49). Peter Bush, for example, notes that only three per cent of what is published in English is translated work, and most of that is done for academic purposes. ${ }^{60}$ It is also possible that, because "translated literature is itself stratified [...] one section of translated literature may assume a central position, [while] another may remain quite peripheral" (49).

\section{BIBLIOGRAPHY}

Arnold, Matthew. 1960. Culture and Anarchy. London: Cambridge University Press. (1869, first edition).

Aveling, Harry. Forthcoming. "Two Approaches to the Positioning of Translations: A Comparative Study of Itamar Even-Zohar's Polysystem Studies and Gideon Toury's Descriptive Translation Studies and Beyond", forthcoming, Kritika Kultura, English Department, Ateneo de Manila University, Philippines.

Beattie, John. 1964. Other Cultures. London: Cohen and West.

Bourdieu, Pierre. 1984. Distinction: A Social Critique of the Judgement of Taste. Cambridge Mass: Harvard University Press.

Bush, Peter and Kirsten Malmkjaer (eds). 1988. Rimbaud's Rainbow: Literary Translation in Higher Education. Amsterdam: John Benjamins.

Champagne, R.A. 1978. "A Grammar of the Languages of Culture: Literary Theory and Yury M. Lotman's Semiotics", New Literary History 9:2 (Winter), pp. 205-210.

60 Introduction, Rimbaud's Rainbow (John Benjamins, Amsterdam 1998), 1. 
Dimic, M.V. and M.K. Garstin. 1988. "The Polysystem Theory: A Brief Introduction, with Bibliography", in E.D. Blodgett and A.G. Purdue (eds), Problems of Literary Reception, University of Alberta, pp. 177-196. On line at http://www.tau.ac.il/itamarez/ps/dimic ps.htm.

Erlich, Victor. 1969. Russian Formalism, History - Doctrine. The Hague: Mouton.

Even-Zohar, Itamar. 1978. Papers in Historical Poetics. Tel Aviv: The Porter Institute for Poetics and Semiotics. Papers previously published in various places and available on-line at http://www.tau.ac.il/ itamarez/ez_vita/ez-publications.htm.

Even-Zohar, Itamar. 1990. "Polysystems Studies", Poetics Today 11:1. Papers previously published in various places and available on line at http://www.tau.ac.il/itamarez/ papers/fac-dep.htm.

Even-Zohar, Itamar. 1998. "Some Replies to Lambert and Pym", Target, 10:2, pp. 363-369.

Even-Zohar, Itamar. 2004/2005. Papers in Culture Research. Papers previously published in various places and collected at http://www.tau.ac.il/ itamarez/ez_vita/ez-publications. htm.

Lambert, José. 1997. “Itamar Even-Zohar's Polysystem Studies: An Interdisciplinary Perspective on Culture Research", Canadian Review of Comparative Literature 24:1 (March), pp. 8-14.

Lotman, J.M., B.A. Uspensky, V.V. Ivanov, V.N. Toporov, and A.M. Pjatigorskij. 1975. “Theses on the Semiotic Study of Cultures (as Applied to Slavic Texts)", in: T.A. Sebeok (ed.), The Tell Tale Sign: A Survey of Semiotics, Lisse: The Peter de Ridder Press, pp. 57-84.

Lotman, Yu.M., B.A. Uspensky and G. MihaychuK. 1978. “On the Semiotic Mechanism of Culture", New Literary History 9:2 (Winter), pp. 211-232.

Matejka, L. and K. Pomorska (eds). 1971. Readings in Russian Poetics. Cambridge: MIT Press.

Nam Fung Chang. 2001. "Polysystem Theory: Its prospect as a framework for translation research", Target 13:2, pp. 317-332.

Pym, Anthony. 1998. “A Note on Repertoire for Seeing Cultures", Target 10:2, pp. 357-361.

Sales Salvador, Dora. 2002. "In Conversation with Itamar Even-Zohar about Literary and Cultural Theory", CLCWeb Library of Research and Information (September). On line at http://clcwebjournal.lib.purdue.edu/clcweb02-3/sales(even-zohar)02.html.

Ann Shukman. 1977. Literature and Semiotics: A Study of the Writings of Yu. M. Lotman. Amsterdam: North-Holland.

Shukman, Ann. 1977. "Soviet Semiotics and Literary Criticism", New Literary History 9:2 (Winter), pp. 189-197.

Swidler, Ann: "Culture in Action: Symbols and Strategies", American Sociological Review, 51:2, (April), 273-286.

Weissbrod, Rachel. 1998. "Translation Research in the Framework of the Tel Aviv School of Poetics and Semiotics", Meta, XLIII:I, pp. 1-12, on line at: www.erudit.org/revue/ meta/1998/v43/n1/004592ar.html. 